Rapid Reviews COVID-19

\title{
Reviews of "Human organ chip-enabled pipeline to rapidly repurpose therapeutics during viral pandemics"
}

Cathryn Sundback ${ }^{1}$, Jeffrey T Borenstein ${ }^{2}$, Ashley L Gard ${ }^{2}$, Jennifer $P$ Wang ${ }^{3}$

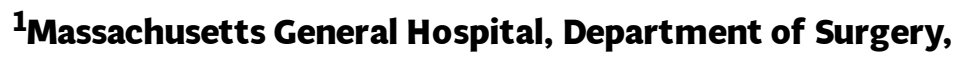

${ }^{2}$ Bioengineering Division, Draper, Cambridge MA,

${ }^{3}$ Department of Medicine, University of Massachusetts Medical School, Worcester MA

Published on: Sep 15, 2020

DOI: $10.1162 / 2 \mathrm{e} 3983 f 5.6 \mathrm{dc} 34 \mathrm{a} 85$

License: Creative Commons Attribution 4.0 International License (CC-BY 4.0). 
To read the original manuscript, click the link above.

Summary of Reviews: This study employs microfluidic devices to test candidate therapeutics blocking SARS-CoV-2 entry and demonstrates amodiaquine efficacy in preclinical models. The claims presented in this work are reliable but could be strengthened through more rigorous model characterization.

\section{Reviewer 1 (Cathryn Sundback) | |}

\section{Reviewer 2 (Jeffrey T Borenstein, Ashley L Gard, Jennifer P Wang)}

$$
\begin{aligned}
& \text { RR:C19 Strength of Evidence Scale Key } \\
& \text { प्रमप = Misleading } \\
& \text { प्र००० = Not Informative } \\
& \text { प्रा पि = Potentially Informative }
\end{aligned}
$$

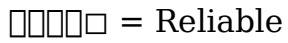

$$
\begin{aligned}
& \text { प्राप्र = Strong }
\end{aligned}
$$

To read the reviews, click the links below. 